\title{
KOMPARASI METODE SAW DAN MOORA DALAM PEMILIHAN JURUSAN PADA SMAN 108 JAKARTA
}

\author{
Alika Putri ${ }^{1}$, Cahyani Budihartanti ${ }^{2}$ \\ Program Studi Sistem Informasi ${ }^{1}$, Program Studi Sistem Informasi ${ }^{2}$ \\ Sistem Informasi ${ }^{1}$, Sistem Informasi ${ }^{2}$ \\ STMIK Nusa Mandiri Jakarta ${ }^{1}$, STMIK Nusa Mandiri Jakarta ${ }^{2}$ \\ putrialika082@gmail.com ${ }^{1}$, cahyani.cbh@ nusamandiri.ac.id ${ }^{2}$
}

\begin{abstract}
ABSTRAK
SMA Negeri 108 Jakarta merupakan salah satu sekolah menengah atas yang berada didaerah Jakarta selatan, di SMA Negeri 108 Jakarta biasanya dilakukan Pemilihan jurusan pada semester ganjil oleh siswa kelas X. Di sekolah ini terbagi dua jurusan yaitu jurusan IPA dan IPS. Pelaksanaan pemilihan jurusan bagi mereka diperkenalkan sebagai upaya untuk mengarahkan siswa terhadap bakat dan minat serta kemampuan akademik siswa tersebut. Tujuan pemilihan jurusan ini agar siswa lebih mudah dalam menentukan jurusan sesuai keinginannya. Penentuan pemilihan jurusan memang terbukti sangat sulit bagi siswa atau orang tua siswa pada era sekarang. Metode yang digunakan dalam pengambilan keputusan pemilihan jurusan pada penelitian ini menggunakan metode SAW dan MOORA dengan mengomparasi penerapan dan hasil dari perhitungan kedua metode tersebut sehingga menghasilkan keputusan yang konsisten dan terbaik. Hasil dari perhitungan kedua metode menjadikan Anggini Sarah sebagai nilai terbesar dengan nilai perhitungan SAW yaitu 24,600 dan hasil perhitungan metode MOORA yaitu 10,451 menjadi jurusan yang terpilih yaitu IPA.
\end{abstract}

Kata kunci: Komparasi, SAW, MOORA, Pemilihan Jurusan

Abstract - SMAN 108 Jakarta is one of the high schools in the south Jakarta area, in the 108 Jakarta High School, the selection of majors is usually done in odd semester by class X students. The school is divided into two majors namely science and social majors. The selection of majors for them was introduced as an effort to direct students towards their students' talents and interests and academic abilities. The purpose of this department selection is for students to more easily determine the department according to their wishes. Determination of the selection of majors indeed proved very difficult for students or parents of students in the current era. The method used in decision making in the selection of majors in this study uses the SAW and MOORA methods by comparing the implementation and results of the calculation of the two methods so as to produce the best and most consistent decisions. The results of the calculation of the two methods make Anggini Sarah the largest value with the SAW calculation value of 24,600 and the MOORA method calculation result of 10.451 being the chosen major, IPA.

Keywords: Comparison, SAW, MOORA, Selection of Departments

\section{PENDAHULUAN}

Penentuan pemilihan jurusan memang terbukti sangat sulit bagi siswa atau orang tua siswa pada era sekarang. Pelaksanaan penjurusan bagi mereka diperkenalkan agar siswa lebih mudah dalam memilih jurusannya. Namun, tidak bisa dipungkiri bahwa ada hal yang lebih penting dalam menentukan pemilihan jurusan yaitu minat siswa terhadap jurusan tersebut. Para siswa yang memiliki ketertarikan dalam suatu jurusan akan lebih menikmatinya, dengan begitu siswa tersebut akan lebih mudah dalam menguasai materi, kompeten dalam implementasi praktek, siap bersaing secara global, serta memiliki minat ketertarikan yang besar di jurusan tersebut.

Pemilihan jurusan biasanya dilakukan serentak disemua sekolah tak terkecuali di SMA Negeri 108 Jakarta yang dilaksanakan pada semester ganjil oleh siswa kelas X. Di sekolah ini terbagi dua jurusan yaitu jurusan IPA dan IPS. Tujuan pemilihan jurusan ini agar siswa lebih mudah dalam menentukan jurusan sesuai keinginannya. Tetapi pemilihan jurusan bagi siswa 
SMA tidak selalu sesuai dengan kemampuan, bakat, minat serta prestasi akademiknya. Kebanyakan penentu pemilihan jurusan itu berdasarkan tiga faktor.

Pertama yaitu berdasarkan adanya referensi orang tua siswa itu sendiri. Kedua, pemilihan minat jurusan didasarkan pada ikut-ikutan teman dan berdasarkan trend jurusan masa kini. Faktor ketiga yaitu prestasi akademik yang dimiliki siswa tersebut. Pemilihan jurusan berdasarkan ketiga faktor tersebut nantinya akan berujung penyesalan bagi siswa yang penjurusannya tidak sesuai dengan bakat, minat dan kesukaan mereka pada jurusan tersebut. Oleh karena itu, sangat dibutuhkannya solusi untuk pengambilan keputusan pemilihan jurusan di Sekolah Menengah Atas[1].

Metode SAW atau Simple Additive Weighting adalah metode yang sering dikenal dengan metode penjumlahan terbobot. Yang hasilnya dari penelitian adalah menentukan nilai bobot untuk setiap atribut atau kriteria, kemudian dilanjutkan dengan proses perankingan yang akan menyeleksi alternatif terbaik dari sejumlah alternatif, dalam hal ini alternatif yang dimaksud adalah penentuan pemilihan jurusan bagi siswa berdasarkan kriteria-kriteria yang ditentukan. Dengan metode perangkingan tersebut, diharapkan penilaian akan lebih tepat karena didasarkan pada nilai kriteria dan bobot yang sudah ditentukan sehingga akan mendapatkan hasil yang lebih akurat[2].

Salah satu metode yang juga dapat digunakan dalam pengambilan keputusan masalah disini adalah dengan menggunakan metode MultiObjective Optimization on the basis of Ratio Analysis atau biasa disebut MOORA. Metode yang diperkenalkan oleh Brauers dan Zavadkas (2006). Metode MOORA ialah metode yang memiliki kalkulasi sederhana. Yang hasilnya dari penelitian yaitu dapat menentukan tujuan dan kriteria yang bertentangan, yaitu kriteria yang bernilai menguntungkan (Benefit) atau yang tidak menguntungkan (Cost)[3]. Dari masalah tersebut maka penulis melakukan penelitian untuk menyelesaikan permasalahan yang terjadi dengan menganalisis suatu sistem yang menghasilkan sebuah informasi.

\section{METODE DAN MATERI}

A. Metode Pengumpulan Data

Ada beberapa metode pengumpulan data yang dilakukan melalui langkah sebagai berikut:

\section{Pengumpulan data primer}

Pengumpulan data primer adalah data yang dikumpulkan sendiri oleh perorangan atau suatu organisasi secara langsung dari objek yang diteliti[4]. Diambil dari hasil wawancara responden berupa kuesioner, maupun data yang diambil dari hasil wawancara, dan pengamat langsung. Kuesioner disebarkan kepada para siswa- siswi SMA Negeri 108 Jakarta sedangkan wawancara dilakukan terhadap Bapak Damri selaku Wakil Kepala Sekolah serta staff-staff yang bisa membantu memberikan informasi

2. Pengumpulan data sekunder

Pengumpulan data sekunder adalah data yang telah dikumpulkan dan disatukan oleh studi-studi sebelumnya atau yang diterbitkan oleh berbagai instasi lain. Dalam penelitian ini data sekunder berupa dari jurnal dan sumber literature lainnya yang berhubungan dengan penelitian mengenai metode SAW dan MOORA.

\section{B. Populasi}

Menurut Ibnu, dkk[5] menyatakan bahwa populasi adalah semua subjek atau objek sasaran penelitian. Wujud subjek itu bermacam-macam bisa berupa manusia, tumbuh-tumbuhan, barang produksi, ungkapan verbal, dokumen, dan barang cetak.

Dalam penelitian ini, yang dimaksud populasi adalah para siswa dan siswi SMA Negeri 108 Jakarta yang dijadikan objek penyebaran kuesioner, serta Bapak Damri selaku Wakil Kepala Sekolah serta staff-staff yang diwawancarai untuk memberikan informasi yang diperlukan dalam penulisan ini.

\section{Sampel Penelitian}

Menurut Arikunto[5] menjelaskan bahwa sampel adalah sebagian atau wakil dari populasi yang diteliti. Dinamakan penelitian sampel apabila hasil penelitian dapat digeneralisasikan kepada populasi. Sampel yang akan diambil harus bersifat presentatif atau memiliki karakteristik yang sama dengan populasi. Yang menjadi sampel penelitian ini adalah para siswa dan siswi yang memilih jurusan perkuliahaan di SMAN Negeri 108 Jakarta, diambil sebanyak 10 responden agar mewakili populasi secara keseluruhan.

\section{Metode Analisis Data}

Metode analisis data merupakan metodologi kualitatif analisis muatan yang berdekatan dengan 
analisis wacana, sedangkan dalam metode kuantitatif analisis muatan yang teramat jelas merupakan salah satu metode pengukuran variabel[6]. Dalam hal ini metode pengolahan dan analisis data yang digunakan yaitu metode simple additive weighting (SAW) dan multi objective optimization by ratio analysis (MOORA) .

\section{Simple Additive Weighting}

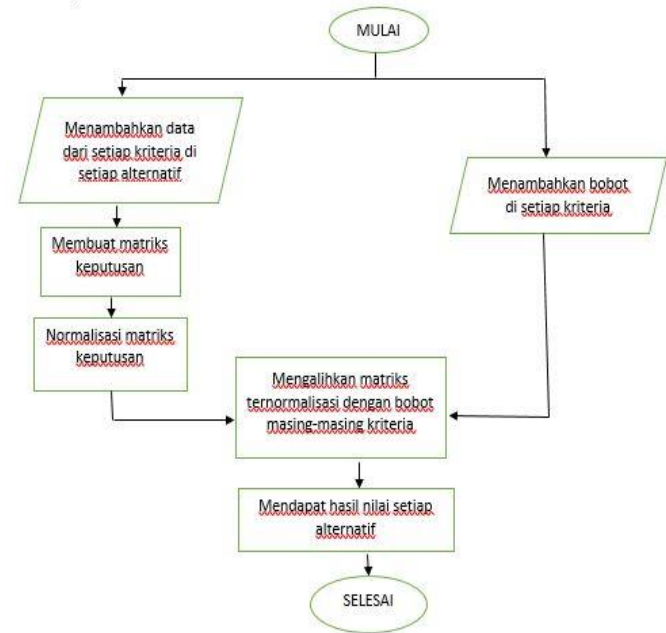

Sumber: Olah Data (2020)

Gambar 1. Tahapan Metode SAW

Metode SAW merupakan suatu metode yang digunakan untuk mencari alternatif optimal dari sejumlah alternatif dengan kriteria tertentu. Inti dari SAW adalah menentukan nilai bobot untuk setiap atribut, kemudian dilanjutkan dengan proses perangkingan yang akan menyeleksi alternatif yang sudah diberikan[7].

Langkah penyelesaian dalam menggunakan metode SAW adalah sebagai berikut:

a. Menentukan alternatif (kandidat).

b. Menentukan kriteria yang akan dijadikan acuan dalam pengambilan keputusan.

c. Memberikan nilai rating kecocokan setiap alternatif pada setiap kriteria.

d. Menenukan bobot preferensi atau tingkat kepentingan untuk setiap kriteria.

e. Membuat tabel rating kecocokan dari setiap alternatif pada setiap kriteria.

f. Membuat matrik keputusan $X$ yang dibentuk dari table rating kecocokan dari setiap alternatif pada setiap kriteria. Nilai X setiap alternatif pada setiap kriteria yang sudah ditentukan. g. Melakukan normalisasi matrik keputusan $\mathrm{X}$ dengan cara menghitung nilai rating kinerja ternormalisasi dari alternatif $\mathrm{Ai}$ pada kriteria $\mathrm{Cj}$ dengan melakukan pengelompokan apakah $\mathrm{j}$ adalah kriteria keuntungan (benefit) atau $\mathrm{j}$ adalah kriteria biaya (cost) maksudnya adalah:

- Dikatakan kriteria keuntungan apabila nilai xij memberikan keuntungan bagi pengambil keputusan, sebaliknya kriteria biaya apabila xij menimbulkan biaya bagi pengambil keputusan.

- Apabila berupa kriteria keuntungan makan nilai xij dibagi dengan nilai Max, i (xij) dari setiap kolom, sedangkan untuk kriteria biaya, nilai Min, i (xij) dari setiap kolom dibagi dengan nilai xij.

h. Hasil dari nilai rating kinerja ternormalisasi (rij) membentuk matrik ternormalisasi.

i. Hasil akhir nilai preferensi diperoleh dari penjumlahan untuk setiap perkalian elemen baris matrik ternormalisasi (R) dengan bobot preferensi (W) yang bersesuaian elemen kolom matrik (W). Hasil perhitungan nilai Vi yang lebih besar mengindikasikan bahwa alternatif Ai merupakan alternatif terbaik.

j. Menentukan nilai indikasi.

k. Perangkingan. Perangkingan dilakukan dengan cara mengalikan nilai SAW dengan nilai indikasi dan hasil akhir dari nilai akan dirangking sesuai urutan hasil yang mempunyai nilai paling besar sampai yang terkecil.

3. Multi Objective Optimization by Ratio Analysis (MOORA) .

Metode MOORA adalah multiobjektif sistem yang mengoptimalkan dua atau lebih attribut yang saling bertentangan secara bersamaan. Metode ini diterapkan untuk memecahkan masalah dengan perhitungan matematika yang kompleks[6].

Langkah-langkah dalam metode MOORA adalah sebagai berikut:

a. Penentuan nilai matrik

Menentukan Tujuan untuk mengindentifikasi atribut evaluasi yang bersangkutan

b. Normalisasi matriks

Mewakilkan semua informasi yang tersedia untuk setiap atrribut dalam bentuk matriks keputusan.

$$
\mathrm{X}=\left[\begin{array}{lll}
\chi_{11} & x_{m 1} & x_{1 n} \\
X_{21} & x_{22} & x_{2 n} \\
x_{m 1} & x_{m 2} & x_{m n}
\end{array}\right]
$$

JISICOM (Journal of Information System, Informatics and Computing)

http://journal.stmikjayakarta.ac.id/index.php/jisicom Telp.+62-21-3905050, e-mail:jisicom@stmikjayakarta.ac.id, jisicom2017@gmail.com 


\section{Journal of Information System, Informatics and Computing}

c. Normalisasi matriks Breaures (2008)

Menyimpulkan bahwa untuk penyebut, pilihan terbaik adalah akar kuadrat dari jumlah kuadrat dan setiap alternatif peratribut.

$$
X_{i j}^{*} \frac{X_{i j}}{\sqrt{\left[\sum_{i=1}^{m} X_{i j}^{2}\right]}}
$$

$$
\text { Untuk j }=12 \ldots \mathrm{m}
$$

d. Mengoptimalkan Atribut

Untuk optimasi Multiobjektif, ukuran yang dinormalisasi ditambahkan dalam kasus maksimasi (untuk atribut yang menguntungkan) dan dikurangi dalam kasus minimasi (untuk atribut yang tidak menguntungkan).

$$
Y_{i} \sum_{j=1}^{g} W_{j}-\sum_{j=g+1}^{n} W_{j} W_{i j}^{*}
$$

Dimana $G$ adalah jumlah atribut yang akan dimaksimalkan, (n-g) adalah jumlah atribut yang akan diminimalkan, dan yi adalah nilai penilaian yang telah dinormalisasikan dari altenatif 1 terhadap semua atribut. Saat atribut bobot dipertimbangkan, persamaan 3 menjadi sebagai berikut

$$
\mathrm{Y} \mathrm{i}=\sum_{j=1}^{g} W_{j} \mathrm{X} * \mathrm{I} \mathrm{j}-\sum_{j=g+1}^{n} W_{j} W_{i j}^{*}
$$

$\mathrm{Wj}$ adalah bobot dari Jth atribut, yang dapat ditentukan dengan menerapkan applying analtic hieararchy process (AHP) atau metode entrophy. e. Perangkingan nilai $\mathrm{Y}$

Nilai Yi bisa positif atau negatif tergantung dari total maksimak dan minimal dalam matriks keputusan. Sebuah urutan peringkat dan Yi menujukan pilihan terakhir.

Alternatif terbaik memiliki nilai Yi tertinggi, sedangkan alternatif terburuk memiliki nilai yang rendah.

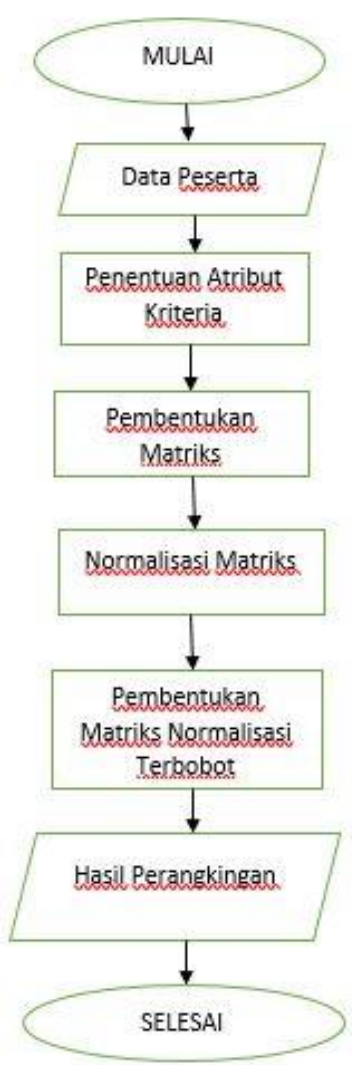

Sumber Olah Data (2020)

Gambar 2. Tahapan Metode MOORA

E. Peralatan pendukung (TOOLS)

Dalam penelitian memerlukan beberapa peralatan pendukung untuk membantu berjalannya proses penelitian, dalam penelitian ini menggunakan Microsoft Excel 2016. Microsoft Excel 2016 merupakan sebuah program spreadsheet versi terbaru yang didesain untuk membantu anda dalam mengelola data anda. Baik itu menyimpan, meringkas, dan menyajikan data. Selain itu anda juga dapat memanfaatkan program ini untuk mencatat produk dan penjualan atau pekerjaan pribadi anda[8]

F. Kriteria-kriteria dan Alternatif-alternatif Pemilihan Jurusan

Dalam menentukan pemilihan jurusan perkuliahaan, ada beberapa kriteria yang digunakan, berikut daftar kriteria-kriterianya:

1. Nilai rata-rata Matematika

2. Nilai rata-rata Bahasa Indonesia

3. Nilai rata-rata Bahasa Indonesia

JISICOM (Journal of Information System, Informatics and Computing) http://journal.stmikjayakarta.ac.id/index.php/jisicom Telp.+62-21-3905050, e-mail:jisicom@stmikjayakarta.ac.id, jisicom2017@gmail.com 
4. Nilai rata-rata Ipa

5. Nilai rata-rata Ips

6. Minat Siswa IPA

7. Minat Siswa IPS

8. Saran Orang Tua IPA

9. Saran Orang Tua IPS

Sedangkan untuk alternatif-alternatif yang telah ditentukan dalam pemilihan jurusan diambil dari siswa-siswi Sman 108 Jakarta tahun 2020:

\section{PEMBAHASAN DAN HASIL}

\section{A. Perhitungan Menggunakan Metode SAW}

Pada tahapan ini akan dilakukan perhitungan dengan menggunakan metode SAW dalam pemilihan jurusan di Sman 108 Jakarta. Data awal
1. Ahmad Prayudha Pangestu

2. Alzikri Rechan Sudecha Pratama

3. Angga Putra Aditia

4. Anggini Sarah El Islami

5. Anjaniva Emillia Jasmine

6. Annisa Alivia Kyandaru

7. Annisa Shabirah

Tabel IV.1. Data Awal Penelitian

\begin{tabular}{|l|c|c|c|c|c|c|c|c|c|}
\hline Alternatif & $\begin{array}{c}\text { Nilai Rata- } \\
\text { rata } \\
\text { Matematika }\end{array}$ & $\begin{array}{c}\text { Nilai Rata- } \\
\text { rata } \\
\text { Bahasa } \\
\text { Indonesia }\end{array}$ & $\begin{array}{c}\text { Nilai } \\
\text { Rata-rata } \\
\text { Bahasa } \\
\text { Inggris }\end{array}$ & $\begin{array}{c}\text { Nilai } \\
\text { Rata- } \\
\text { rata } \\
\text { IPS }\end{array}$ & $\begin{array}{c}\text { Nilai } \\
\text { Rata- } \\
\text { rata } \\
\text { IPA }\end{array}$ & $\begin{array}{c}\text { Minat } \\
\text { Siswa } \\
\text { IPA }\end{array}$ & $\begin{array}{c}\text { Minat } \\
\text { Siswa } \\
\text { IPS }\end{array}$ & $\begin{array}{c}\text { Saran } \\
\text { Orang } \\
\text { Tua } \\
\text { IPA }\end{array}$ & $\begin{array}{c}\text { Saran } \\
\text { Orang } \\
\text { Tua } \\
\text { IPS }\end{array}$ \\
\hline $\begin{array}{l}\text { Ahmad } \\
\text { Prayudha }\end{array}$ & 82 & 86 & 82 & 78 & 86 & SM & KM & SM & TM \\
\hline $\begin{array}{l}\text { Alzikri } \\
\text { Rechan }\end{array}$ & 77 & 83 & 80 & 80 & 78 & SM & TM & SM & KM \\
\hline $\begin{array}{l}\text { Angga } \\
\text { Putra }\end{array}$ & 77 & 82 & 73 & 80 & 77 & M & C & SM & KM \\
\hline $\begin{array}{l}\text { Anggini } \\
\text { Sarah }\end{array}$ & 84 & 86 & 82 & 84 & 85 & SM & KM & M & KM \\
\hline $\begin{array}{l}\text { Anjaniva } \\
\text { Emilia }\end{array}$ & 88 & 84 & 83 & 86 & 90 & KM & SM & TM & SM \\
\hline $\begin{array}{l}\text { Annisa } \\
\text { Alivia }\end{array}$ & 89 & 87 & 89 & 84 & 89 & KM & M & CM & M \\
\hline $\begin{array}{l}\text { Annisa } \\
\text { Sahabirah }\end{array}$ & 82 & 80 & 80 & 85 & 84 & C & SM & CM & M \\
\hline
\end{tabular}

Dari data awal diatas, akan diolah menggunakan metode SAW. Tahapan-tahapan dalam metode SAW adalah sebagai berikut:

1. Menentukan Kriteria

Dalam metode SAW terdapat kriteria yang dibutuhkan untuk proses perhitungan nantinya. Dalam kasus ini ada 9 kriteria yang akan digunakan untuk proses pengambilan keputusan menentukan jurusan. Kriteria-kriteria tersebut adalah:

1. Nilai rata-rata Matematika

2. Nilai rata-rata Bahasa Indonesia

3. Nilai rata-rata Bahasa Inggris

4. Nilai rata-rata IPA diperoleh dari penelitian yang dilakukan dari hasil wawancara oleh Bapak Damri selaku wakil kepala sekolah. Diperoleh data awal adalah sebagai berikut: 


\section{Journal of Information System, Informatics and Computing}

\begin{tabular}{|l|c|}
\hline Nilai Rata-rata Matematika & 5 \\
\hline $\begin{array}{l}\text { Nilai Rata-rata Bahasa } \\
\text { Indonesia }\end{array}$ & 4,5 \\
\hline $\begin{array}{l}\text { Nilai Rata-rata Bahasa } \\
\text { Inggris }\end{array}$ & 4 \\
\hline Nilai Rata-rata IPA & 3,5 \\
\hline Nilai Rata-rata IPS & 3 \\
\hline Minat Siswa IPA & 2,5 \\
\hline Minat Siswa IPS & 2 \\
\hline Saran Orang Tua IPA & 1,5 \\
\hline Saran Orang Tua IPS & 1 \\
\hline
\end{tabular}

Sumber: Olah Data (2020)

3. Menentukan Tabel Rating Kriteria Kecocokan

a. Kriteria Nilai Rata-rata Matematika

Nilai rata-rata matematika di ambil dari siswa saat belajar dibangku SMP, dan nilainya. Dilihat dari nilai rata-rata semester 1 sampai 6 .

Tabel IV.3 Komposisi penilaian Nilai Rata-rata Matematika

\begin{tabular}{|c|c|c|}
\hline $\begin{array}{c}\text { Nilai Rata-rata } \\
\text { Matematika }\end{array}$ & Klasifikasi & Rating \\
\hline $91-100$ & Sangat Baik & 5 \\
\hline $81-90$ & Baik & 4 \\
\hline $71-80$ & Cukup & 3 \\
\hline $61-70$ & Kurang & 2 \\
\hline $51-60$ & Sangat Kurang & 1 \\
\hline
\end{tabular}

Sumber: Olah Data (2020)

b. Kriteria Nilai Rata-rata Bahasa Indonesia Nilai rata-rata Bahasa Indonesia di ambil dari siswa saat belajar dibangku SMP, dan nilainya dilihat dari nilai rata-rata semester 1 sampai 6 (lihat tabel IV.4)

Tabel IV.4 Komposisi penilaian Nilai Rata-rata Bahasa Indonesia

\begin{tabular}{|c|c|c|}
\hline $\begin{array}{c}\text { Nilai Rata-rata } \\
\text { Bahasa Indonesia }\end{array}$ & Klasifikasi & Rating \\
\hline $91-100$ & Sangat Baik & 5 \\
\hline $81-90$ & Baik & 4 \\
\hline $71-80$ & Cukup & 3 \\
\hline $61-70$ & Kurang & 2 \\
\hline $51-60$ & Sangat Kurang & 1 \\
\hline
\end{tabular}

Sumber: Olah Data (2020)

c. Kriteria Nilai Rata-rata Bahasa Inggris

Nilai rata-rata Bahasa Inggris di ambil dari siswa saat belajar dibangku SMP, dan nilainya dilihat dari nilai rata-rata semester 1 sampai 6 .

Tabel IV.5 Komposisi penilaian Nilai Rata-rata Bahasa Inggris

\begin{tabular}{|c|c|c|}
\hline $\begin{array}{c}\text { Nilai Rata-rata } \\
\text { Bahasa Inggris }\end{array}$ & Klasifikasi & Rating \\
\hline $91-100$ & Sangat Baik & 5 \\
\hline $81-90$ & Baik & 4 \\
\hline $71-80$ & Cukup & 3 \\
\hline $61-70$ & Kurang & 2 \\
\hline $51-60$ & Sangat Kurang & 1 \\
\hline
\end{tabular}

Sumber: Olah Data (2020)

d. Kriteria Nilai Rata-rata IPA

Nilai rata-rata IPA di ambil dari siswa saat belajar dibangku SMP, dan nilainya dilihat dari nilai rata-rata semester 1 sampai 6.

Tabel IV.6 Komposisi penilaian Nilai Rata-rata IPA

\begin{tabular}{|c|c|c|}
\hline Nilai Rata-rata IPA & Klasifikasi & Rating \\
\hline $91-100$ & Sangat Baik & 5 \\
\hline $81-90$ & Baik & 4 \\
\hline $71-80$ & Cukup & 3 \\
\hline $61-70$ & Kurang & 2 \\
\hline $51-60$ & Sangat Kurang & 1 \\
\hline
\end{tabular}

Sumber: Olah Data (2020)

e. Kriteria Nilai Rata-rata IPS

Nilai rata-rata IPS di ambil dari siswa saat belajar dibangku SMP, dan nilainya dilihat dari nilai rata-rata semester 1 sampai 6 .

Tabel IV.7 Komposisi penilaian Nilai Rata-rata IPS

\begin{tabular}{|c|c|c|}
\hline Nilai Rata-rata IPS & Klasifikasi & Rating \\
\hline $91-100$ & Sangat Baik & 5 \\
\hline $81-90$ & Baik & 4 \\
\hline $71-80$ & Cukup & 3 \\
\hline $61-70$ & Kurang & 2 \\
\hline $51-60$ & Sangat Kurang & 1 \\
\hline
\end{tabular}

Sumber: Olah Data (2020)

f. Kriteria Minat Siswa IPA

Minat Siswa IPA ini didapat saat siswa melakukan pendaftaran ke sekolah SMA dengan melakukan pengisian Formulir.

Tabel IV.8 Komposisi Penilaian Minat IPA

\begin{tabular}{|l|l|c|}
\hline Kriteria & Klasifikasi & Rating \\
\hline \multirow{4}{*}{ Minat Siswa IPA } & Sangat Minat (SM) & 5 \\
\cline { 2 - 3 } & Minat (M) & 4 \\
\cline { 2 - 3 } & Cukup (C) & 3 \\
\cline { 2 - 3 } & Kurang Minat (KM) & 2 \\
\cline { 2 - 3 } & Tidak MInat (TM) & 1 \\
\hline
\end{tabular}

Sumber: Olah Data (2020)

g. Kriteria Minat Siswa IPS

JISICOM (Journal of Information System, Informatics and Computing) http://journal.stmikjayakarta.ac.id/index.php/jisicom Telp.+62-21-3905050, e-mail:jisicom@stmikjayakarta.ac.id, jisicom2017@gmail.com 


\section{Journal of Information System, Informatics and Computing}

Minat Siswa IPS ini didapat saat siswa melakukan pendaftaran ke sekolah SMA dengan melakukan pengisian Formulir.

Tabel IV.9 Komposisi Penilaian Minat IPS

\begin{tabular}{|c|c|c|}
\hline Kriteria & Klasifikasi & Rating \\
\hline \multirow{4}{*}{ Minat Siswa IPS } & Sangat Minat (SM) & 5 \\
\cline { 2 - 3 } & Minat (M) & 4 \\
\cline { 2 - 3 } & Cukup (C) & 3 \\
\cline { 2 - 3 } & Kurang Minat (KM) & 2 \\
\cline { 2 - 3 } & Tidak MInat (TM) & 1 \\
\hline
\end{tabular}

Sumber: Olah Data (2020)

h. Kriteria Saran Orang Tua Siswa IPA

Saran Orang Tua IPA ini didapat saat siswa melakukan pendaftaran ke sekolah SMA dengan melakukan pengisian Formulir.

Tabel IV.10 Komposisi Penilaian Saran Orang Tua IPA

\begin{tabular}{|c|c|c|}
\hline \multirow{4}{*}{ Kriteria } & Klasifikasi & $\begin{array}{c}\text { Ratin } \\
\mathrm{g}\end{array}$ \\
\hline \multirow{4}{*}{$\begin{array}{c}\text { Saran Orang Tua } \\
\text { IPA }\end{array}$} & $\begin{array}{c}\text { Sangat Menyarankan } \\
\text { (SM) }\end{array}$ & 5 \\
\cline { 2 - 3 } & Menyarankan (M) & 4 \\
\cline { 2 - 3 } & $\begin{array}{c}\text { Kurang Menyarankan } \\
\text { (KM) }\end{array}$ & 3 \\
\cline { 2 - 3 } & $\begin{array}{c}\text { Tidak Menyarankan } \\
\text { (TM) }\end{array}$ & 1 \\
\hline
\end{tabular}

Sumber: Olah Data (2020)

i. Kriteria Saran Orang Tua Siswa IPS

Saran Orang Tua IPS ini didapat saat siswa melakukan pendaftaran ke sekolah SMA dengan melakukan pengisian Formulir.

Tabel IV.11 Komposisi Penilaian Saran Orang Tua IPS

\begin{tabular}{|c|c|c|}
\hline \multirow{4}{*}{ Kriteria } & Klasifikasi & $\begin{array}{c}\text { Ratin } \\
\mathrm{g}\end{array}$ \\
\hline \multirow{4}{*}{$\begin{array}{c}\text { Saran Orang Tua } \\
\text { IPS }\end{array}$} & $\begin{array}{c}\text { Sangat Menyarankan } \\
\text { (SM) }\end{array}$ & 5 \\
\cline { 2 - 3 } & Menyarankan (M) & 4 \\
\cline { 2 - 3 } & $\begin{array}{c}\text { Kurang Menyarankan } \\
\text { (KM) }\end{array}$ & 2 \\
\cline { 2 - 3 } & $\begin{array}{c}\text { Tidak Menyarankan } \\
\text { (TM) }\end{array}$ & 1 \\
\hline
\end{tabular}

Sumber: Olah Data (2020)

4. Membuat Rating kecocokan pada alternatif

Membuat tabel rating kecocokan pada alternatif dari Ahmad Prayudha, Alzikri Rechan, Angga Rechan, Angga Putra,Anggini Sarah, Anjaniya Emilia, Annisa Alivia,Annisa Sahabirah setiap kriteria.

\begin{tabular}{|l|c|c|c|c|c|c|c|c|c|}
\hline \multicolumn{10}{|c|}{ Tabel IV.12 Rating kecocokan dari data awal } \\
Alternatif & $\begin{array}{c}\text { Nilai Rata- } \\
\text { rata } \\
\text { Matematika }\end{array}$ & $\begin{array}{c}\text { Nilai Rata- } \\
\text { rata } \\
\text { Bahasa } \\
\text { Indonesia }\end{array}$ & $\begin{array}{c}\text { Nilai } \\
\text { Rata-rata } \\
\text { Bahasa } \\
\text { Inggris }\end{array}$ & $\begin{array}{c}\text { Nilai } \\
\text { Rata- } \\
\text { rata } \\
\text { IPS }\end{array}$ & $\begin{array}{c}\text { Nilai } \\
\text { Rata- } \\
\text { rata } \\
\text { IPA }\end{array}$ & $\begin{array}{c}\text { Minat } \\
\text { Siswa } \\
\text { IPA }\end{array}$ & $\begin{array}{c}\text { Minat } \\
\text { Siswa } \\
\text { IPS }\end{array}$ & $\begin{array}{c}\text { Saran } \\
\text { Orang } \\
\text { Tua } \\
\text { IPA }\end{array}$ & $\begin{array}{c}\text { Saran } \\
\text { Orang } \\
\text { Tua } \\
\text { IPS }\end{array}$ \\
\hline $\begin{array}{l}\text { Ahmad } \\
\text { Prayudha }\end{array}$ & 82 & 86 & 82 & 78 & 86 & SM & KM & SM & TM \\
\hline $\begin{array}{l}\text { Alzikri } \\
\text { Rechan }\end{array}$ & 77 & 83 & 80 & 80 & 78 & SM & TM & SM & KM \\
\hline $\begin{array}{l}\text { Angga } \\
\text { Putra }\end{array}$ & 77 & 82 & 73 & 80 & 77 & M & C & SM & KM \\
\hline $\begin{array}{l}\text { Anggini } \\
\text { Sarah }\end{array}$ & 84 & 86 & 82 & 84 & 85 & SM & KM & M & KM \\
\hline $\begin{array}{l}\text { Anjaniva } \\
\text { Emilia }\end{array}$ & 88 & 84 & 83 & 86 & 90 & KM & SM & TM & SM \\
\hline $\begin{array}{l}\text { Annisa } \\
\text { Alivia }\end{array}$ & 89 & 87 & 89 & 84 & 89 & KM & M & CM & M \\
\hline $\begin{array}{l}\text { Annisa } \\
\text { Sahabirah }\end{array}$ & 82 & 80 & 80 & 85 & 84 & C & SM & CM & M \\
\hline
\end{tabular}

Sumber: Olah Data (2020) 


\section{Journal of Information System, Informatics and Computing}

Vol.4 No.2 Desember 2020

e-ISSN : 2597-3673 (Online)

p-ISSN : 2579-5201 (Printed)

Dari Tabel IV.12 diatas, selanjutnya akan dibentuk rating kecocokan dari setiap alternatif seperti pada tabel dibawah ini:

Tabel.13 Rating Kecocokan dari alternatif

\begin{tabular}{|c|c|c|c|c|c|c|c|c|c|}
\hline Alternatif & C1 & C2 & C3 & C4 & C5 & C6 & C7 & C8 & C9 \\
\hline Ahmad Prayudha & 4 & 4 & 4 & 3 & 4 & 5 & 2 & 5 & 1 \\
\hline Alzikri Rechan & 3 & 4 & 3 & 3 & 3 & 5 & 1 & 5 & 2 \\
\hline Angga Putra & 3 & 4 & 3 & 3 & 3 & 4 & 3 & 5 & 2 \\
\hline Anggini Sarah & 4 & 4 & 4 & 4 & 4 & 5 & 2 & 3 & 2 \\
\hline Anjaniya Emilia & 4 & 4 & 4 & 4 & 4 & 2 & 5 & 1 & 5 \\
\hline Annisa Alivia & 4 & 4 & 4 & 4 & 4 & 2 & 4 & 3 & 4 \\
\hline Annisa Sahabirah & 4 & 3 & 3 & 4 & 4 & 3 & 5 & 3 & 4 \\
\hline
\end{tabular}

Sumber: Olah Data (2020)

Dari tabel.13 rating kecocokan alternatif, langkah selanjutnya yaitu membentuk matriks keputusan (matriks x).

5. Membuat matriks keputusan (x)

Dari tabel IV.13 rating kecocokan alternatif, langkah selanjutnya yaitu membentuk matriks keputusan (x), yaitu sebagai berikut:

$$
\mathrm{X}=\left(\begin{array}{lllllllll}
4 & 4 & 4 & 3 & 4 & 5 & 2 & 5 & 1 \\
3 & 4 & 3 & 3 & 3 & 5 & 1 & 5 & 2 \\
3 & 4 & 3 & 3 & 3 & 4 & 3 & 5 & 2 \\
4 & 4 & 4 & 4 & 4 & 5 & 2 & 3 & 2 \\
4 & 4 & 4 & 4 & 4 & 2 & 5 & 1 & 5 \\
4 & 4 & 4 & 4 & 4 & 2 & 4 & 3 & 4 \\
4 & 3 & 3 & 4 & 4 & 3 & 5 & 3 & 4
\end{array}\right)
$$

6. Membuat matriks keputusan

ternormalisasi (x)

Langkah selanjutnya dalam metode SAW melakukan normalisasi matriks keputusan X dengan cara menghitung nilai rating kinerja ternormalisasi (Rij) dari alternatif (Ai) pada kriteria $(\mathrm{Cj})$, yaitu sebagai berikut:

$$
\begin{aligned}
& R 11=\frac{4}{\operatorname{Maks}(4,3,3,4,4,4,4)}=\frac{4}{4}=1 \\
& R 12=\frac{3}{\operatorname{Maks}(4,3,3,4,4,4,4)}=\frac{3}{4}=0,75 \\
& R 13=\frac{3}{\operatorname{Maks}(4,3,3,4,4,4,4)}=\frac{3}{4}=0,75 \\
& R 14=\frac{4}{\operatorname{Maks}(4,3,3,4,4,4,4)}=\frac{4}{4}=1
\end{aligned}
$$

$$
\begin{aligned}
& R 15=\frac{4}{\operatorname{Maks}(4,3,3,4,4,4,4)}=\frac{4}{4}=1 \\
& R 16=\frac{4}{\operatorname{Maks}(4,3,3,4,4,4,4)}=\frac{4}{4}=1 \\
& R 17=\frac{4}{\operatorname{Maks}(4,3,3,4,4,4,4)}=\frac{4}{4}=1 \\
& R 21=\frac{4}{\operatorname{Maks}(4,4,4,4,4,4,3)}=\frac{4}{4}=1 \\
& R 22=\frac{4}{\operatorname{Maks}(4,4,4,4,4,4,3)}=\frac{4}{4}=1 \\
& R 23=\frac{4}{\operatorname{Maks}(4,4,4,4,4,4,3)}=\frac{4}{4}=1
\end{aligned}
$$$$
R 24=\frac{4}{\operatorname{Maks}(4,4,4,4,4,4,3)}=\frac{4}{4}=1
$$$$
R 25=\frac{4}{\operatorname{Maks}(4,4,4,4,4,4,3)}=\frac{4}{4}=1
$$$$
R 26=\frac{4}{\operatorname{Maks}(4,4,4,4,4,4,3)}=\frac{4}{4}=1
$$$$
R 27=\frac{3}{\operatorname{Maks}(4,4,4,4,4,4,3)}=\frac{3}{4}=0,75
$$$$
R 31=\frac{4}{\operatorname{Maks}(4,3,3,4,4,4,3)}=\frac{4}{4}=1
$$ 


$$
\begin{aligned}
& R 32=\frac{3}{\operatorname{Maks}(4,3,3,4,4,4,3)}=\frac{3}{4}=0,75 \\
& R 33=\frac{3}{\operatorname{Maks}(4,3,3,4,4,4,3)}=\frac{3}{4}=0,75 \\
& R 34=\frac{4}{\operatorname{Maks}(4,3,3,4,4,4,3)}=\frac{4}{4}=1 \\
& R 35=\frac{4}{\operatorname{Maks}(4,3,3,4,4,4,3)}=\frac{4}{4}=1 \\
& R 36=\frac{4}{\operatorname{Maks}(4,3,3,4,4,4,3)}=\frac{4}{4}=1 \\
& R 37=\frac{3}{\operatorname{Maks}(4,3,3,4,4,4,3)}=\frac{3}{4}=0,75 \\
& R 41=\frac{3}{\operatorname{Maks}(3,3,3,4,4,4,4)}=\frac{3}{4}=0,75 \\
& R 42=\frac{3}{\operatorname{Maks}(3,3,3,4,4,4,4)}=\frac{3}{4}=0,75 \\
& R 43=\frac{3}{\operatorname{Maks}(3,3,3,4,4,4,4)}=\frac{3}{4}=0,75 \\
& R 44=\frac{4}{\operatorname{Maks}(3,3,3,4,4,4,4)}=\frac{4}{4}=1 \\
& R 45=\frac{4}{\operatorname{Maks}(3,3,3,4,4,4,4)}=\frac{4}{4}=1 \\
& R 46=\frac{4}{\operatorname{Maks}(3,3,3,4,4,4,4)}=\frac{4}{4}=1 \\
& R 47=\frac{4}{\operatorname{Maks}(3,3,3,4,4,4,4)}=\frac{4}{4}=1 \\
& R 51=\frac{4}{\operatorname{Maks}(4,3,3,4,4,4,4)}=\frac{4}{4}=1 \\
& R 52=\frac{3}{\operatorname{Maks}(4,3,3,4,4,4,4)}=\frac{3}{4}=0,75 \\
& R 53=\frac{3}{\operatorname{Maks}(4,3,3,4,4,4,4)}=\frac{3}{4}=0,75
\end{aligned}
$$$$
R 54=\frac{4}{\operatorname{Maks}(4,3,3,4,4,4,4)}=\frac{4}{4}=1
$$$$
\begin{aligned}
& R 55=\frac{4}{\operatorname{Maks}(4,3,3,4,4,4,4)}=\frac{4}{4}=1 \\
& R 56=\frac{4}{\operatorname{Maks}(4,3,3,4,4,4,4)}=\frac{4}{4}=1 \\
& R 57=\frac{4}{\operatorname{Maks}(4,3,3,4,4,4,4)}=\frac{4}{4}=1
\end{aligned}
$$$$
R 61=\frac{5}{\operatorname{Maks}(5,5,4,5,2,2,3)}=\frac{5}{5}=1
$$$$
R 62=\frac{5}{\operatorname{Maks}(5,5,4,5,2,2,3)}=\frac{5}{5}=1
$$$$
R 63=\frac{4}{\operatorname{Maks}(5,5,4,5,2,2,3)}=\frac{4}{5}=0,8
$$$$
R 64=\frac{5}{\operatorname{Maks}(5,5,4,5,2,2,3)}=\frac{5}{5}=1
$$$$
R 65=\frac{2}{\operatorname{Maks}(5,5,4,5,2,2,3)}=\frac{2}{5}=0,4
$$$$
R 66=\frac{2}{\operatorname{Maks}(5,5,4,5,2,2,3)}=\frac{2}{5}=0,4
$$$$
R 67=\frac{3}{\operatorname{Maks}(5,5,4,5,2,2,3)}=\frac{3}{5}=0,6
$$$$
R 71=\frac{2}{\operatorname{Maks}(2,1,3,2,5,4,5)}=\frac{2}{5}=0,4
$$$$
R 72=\frac{1}{\operatorname{Maks}(2,1,3,2,5,4,5)}=\frac{1}{5}=0,2
$$$$
R 73=\frac{3}{\operatorname{Maks}(2,1,3,2,5,4,5)}=\frac{3}{5}=0,6
$$$$
R 74=\frac{2}{\operatorname{Maks}(2,1,3,2,5,4,5)}=\frac{2}{5}=0,4
$$$$
R 75=\frac{5}{\operatorname{Maks}(2,1,3,2,5,4,5)}=\frac{5}{5}=1
$$ 


$$
\begin{aligned}
& R 76=\frac{4}{\operatorname{Maks}(2,1,3,2,5,4,5)}=\frac{4}{5}=0,8 \\
& R 77=\frac{5}{\operatorname{Maks}(2,1,3,2,5,4,5)}=\frac{5}{5}=1 \\
& R 81=\frac{5}{\operatorname{Maks}(5,5,5,3,1,3,3)}=\frac{5}{5}=1 \\
& R 82=\frac{5}{\operatorname{Maks}(5,5,5,3,1,3,3)}=\frac{5}{5}=1 \\
& R 83=\frac{5}{\operatorname{Maks}(5,5,5,3,1,3,3)}=\frac{5}{5}=1 \\
& R 84=\frac{3}{\operatorname{Maks}(5,5,5,3,1,3,3)}=\frac{3}{5}=0,6 \\
& R 85=\frac{1}{\operatorname{Maks}(5,5,5,3,1,3,3)}=\frac{1}{5}=0,2 \\
& R 86=\frac{3}{\operatorname{Maks}(5,5,5,3,1,3,3)}=\frac{3}{5}=0,6 \\
& R 87=\frac{3}{\operatorname{Maks}(5,5,5,3,1,3,3)}=\frac{3}{5}=0,6 \\
& R 91=\frac{1}{\operatorname{Maks}(1,2,2,2,5,4,4)}=\frac{1}{5}=0,2 \\
& R 92=\frac{2}{\operatorname{Maks}(1,2,2,2,5,4,4)}=\frac{2}{5}=0,4 \\
& R 93=\frac{2}{\operatorname{Maks}(1,2,2,2,5,4,4)}=\frac{2}{5}=0,4 \\
& R 94=\frac{2}{\operatorname{Maks}(1,2,2,2,5,4,4)}=\frac{2}{5}=0,4 \\
& R 95=\frac{5}{\operatorname{Maks}(1,2,2,2,5,4,4)}=\frac{5}{5}=1 \\
& R 96=\frac{4}{\operatorname{Maks}(1,2,2,2,5,4,4)}=\frac{4}{5}=0,8 \\
& R 97=\frac{4}{\operatorname{Maks}(1,2,2,2,5,4,4)}=\frac{4}{5}=0,8
\end{aligned}
$$

Dari hasil perhitungan persamaan diatas, maka didapat sebuah nilai matriks ternormalisasi (R) yaitu sebagai berikut:

7. Menghitung Nilai Preferensi (Vi)

Langkah kedelapan menghitung hasil akhir nilai preferensi (Vi) diperoleh dari penjumlahan dari perkalian elemen baris matriks ternormalisasi (R) dengan bobot preferensi (W) yang bersesuaian dengan elemen kolom matriks (R).

$$
\begin{aligned}
\mathrm{V} 1= & (1,00)(5,0)+(1,00)(4,5)+(1,00)(4,0) \\
& +(0,75)(3,5)+(1,00)(3,0)+(1,00) \\
& (2,5)+(0,40)(2,0)+(1,00)(1,5)+ \\
& (0,20)(1,0)=\mathbf{2 4 , 1 2 5} \\
\mathrm{V} 2= & (0,75)(5,0)+(1,00)(4,5)+(0,75)(4,0) \\
& +(0,75)(3,5)+(0,75)(3,0)+(1,00)(2,5) \\
& +(0,20)(2,0)+(1,00)(1,5)+(0,40) \\
& (1,0)=\mathbf{2 0 , 9 2 5} \\
\mathrm{V} 3= & (0,75)(5,0)+(1,00)(4,5)+(0,75)(4,0) \\
& +(0,75)(3,5)+(0,75)(3,0)+(0,80) \\
& (2,5)+(0,60)(2,0)+(1,00)(1,5)+ \\
& (0,40)(1,0)=\mathbf{2 1 , 2 2 5} \\
\mathrm{V} 4= & (1,00)(5,0)+(1,00)(4,5)+(1,00)(4,0) \\
& +(1,00)(3,5)+(1,00)(3,0)+(1,00) \\
& (2,5)+(0,40)(2,0)+(0,60)(1,5)+ \\
& (0,40)(1,0)=\mathbf{2 4 , 6 0 0} \\
\mathrm{V} 5= & (1,00)(5,0)+(1,00)(4,5)+(1,00)(4,0) \\
& +(1,00)(3,5)+(1,00)(3,0)+(0,40) \\
& (2,5)+(1,00)(2,0)+(0,20)(1,5)+ \\
& (1,00)(1,0)=\mathbf{2 4 , 3 0 0} \\
\mathrm{V6}= & (1,00)(5,0)+(1,00)(4,5)+(1,00)(4,0) \\
& +(1,00)(3,5)+(1,00)(3,0)+(0,40) \\
& (2,5)+(0,80)(2,0)+(0,60)(1,5)+ \\
\mathrm{V} 7= & (1,00)(5,0)+(0,75)(4,5)+(0,75)(4,0) \\
& +(1,00)(3,5)+(1,00)(3,0)+(0,60) \\
& (2,5)+(1,00)(2,0)+(0,60)(1,5)+ \\
& (0,80)(1,0)=\mathbf{2 3 , 0 7 5}
\end{aligned}
$$

Berdasarkan hasil nilai preferensi diatas maka dibuat tabel perangkingan sebagai berikut:

Tabel.14 hasil perangkingan

\begin{tabular}{|c|c|c|c|}
\hline $\begin{array}{c}\text { Alternati } \\
\text { f }\end{array}$ & Keterangan & Skor & Peringkat \\
\hline S1 & Ahmad Prayudha & 24,125 & 4 \\
\hline S2 & Alzikri Rechan & 20,925 & 7 \\
\hline S3 & Angga Putra & 21,225 & 6 \\
\hline S4 & Anggini Sarah & 24,600 & 1 \\
\hline
\end{tabular}




\begin{tabular}{|c|c|c|c|} 
S5 & Anjaniva Emilia & 24,300 & 2 \\
\hline S6 & Annisa Alivia & 24,300 & 3 \\
\hline S7 & Annisa Sahabirah & 23,075 & 5 \\
\hline
\end{tabular}

Sumber: Olah Data (2020)

Berdasarkan tabel.13 hasil perangkingan maka peringkat 1 sampai peringkat 4 masuk ke dalam jurusan IPA dan sisanya peringkat 5 sampai 7 masuk ke dalam jurusan IPS. Maka siswa yang masuk jurusan IPA adalah Anggini Sarah, Anjaniva Emilia, Annisa Alivia, Ahmad Prayudha dan yang masuk IPS adalah Annisa Sahabirah, Angga Putra, Alzikri Rechan.

\section{a. Perhitungan Menggunakan Metode \\ MOORA}

Pada tahapan ini akan dilakukan perhitungan dengan menggunakan metode MOORA dalam pemilihan jurusan di Sman 108 Jakarta. Data awal diperoleh dari penelitian yang dilakukan dari hasil wawancara oleh Bapak Damri selaku wakil kepala sekolah. Diperoleh data awal adalah sebagai berikut:

Tabel.15 Data awal

\begin{tabular}{|c|c|c|c|c|c|c|c|c|c|}
\hline $\begin{array}{l}\text { Alt } \\
\text { ern } \\
\text { atif }\end{array}$ & $\begin{array}{c}\text { Nila } \\
\text { i } \\
\text { Rat } \\
\text { a- } \\
\text { rata } \\
\text { Mat } \\
\text { ema } \\
\text { tika }\end{array}$ & $\begin{array}{c}\text { Nil } \\
\text { ai } \\
\text { Rat } \\
\text { a- } \\
\text { rat } \\
\text { a } \\
\mathrm{Ba} \\
\text { has } \\
\text { a } \\
\text { Ind } \\
\text { one } \\
\text { sia }\end{array}$ & $\begin{array}{l}\mathrm{Ni} \\
\text { lai } \\
\mathrm{R} \\
\text { at } \\
\text { a- } \\
\text { rat } \\
\text { a } \\
\text { B } \\
\text { ah } \\
\text { as } \\
\text { a } \\
\text { In } \\
\text { gg } \\
\text { ris }\end{array}$ & $\begin{array}{l}\mathrm{N} \\
\text { il } \\
\text { ai } \\
\mathrm{R} \\
\text { at } \\
\text { a- } \\
\text { ra } \\
\text { ta } \\
\text { I } \\
\text { P } \\
\text { S }\end{array}$ & $\begin{array}{l}\mathrm{N} \\
\text { il } \\
\text { ai } \\
\mathrm{R} \\
\text { at } \\
\text { a- } \\
\text { ra } \\
\text { ta } \\
\text { I } \\
\text { P } \\
\text { A }\end{array}$ & $\begin{array}{l}\mathrm{M} \\
\text { in } \\
\text { at } \\
\mathrm{Si} \\
\mathrm{S} \\
\mathrm{W} \\
\mathrm{a} \\
\mathrm{IP} \\
\mathrm{A}\end{array}$ & $\begin{array}{l}\mathrm{M} \\
\text { in } \\
\text { at } \\
\mathrm{Si} \\
\mathrm{S} \\
\mathrm{W} \\
\text { a } \\
\text { IP } \\
\mathrm{S}\end{array}$ & $\begin{array}{c}\mathrm{S} \\
\mathrm{ar} \\
\mathrm{a} \\
\mathrm{n} \\
\mathrm{O} \\
\mathrm{ra} \\
\mathrm{n} \\
\mathrm{g} \\
\mathrm{T} \\
\mathrm{u} \\
\mathrm{a} \\
\mathrm{IP} \\
\mathrm{A}\end{array}$ & $\begin{array}{c}\mathrm{S} \\
\mathrm{ar} \\
\mathrm{a} \\
\mathrm{n} \\
\mathrm{O} \\
\mathrm{ra} \\
\mathrm{n} \\
\mathrm{g} \\
\mathrm{T} \\
\mathrm{u} \\
\mathrm{a} \\
\mathrm{IP} \\
\mathrm{S}\end{array}$ \\
\hline $\begin{array}{l}\text { Ah } \\
\text { ma } \\
\text { d } \\
\text { Pra } \\
\text { yu } \\
\text { dha }\end{array}$ & 82 & 86 & 82 & $\begin{array}{l}7 \\
8\end{array}$ & $\begin{array}{l}8 \\
6\end{array}$ & $\begin{array}{c}\mathrm{S} \\
\mathrm{M}\end{array}$ & $\begin{array}{l}\mathrm{K} \\
\mathrm{M}\end{array}$ & $\begin{array}{c}\mathrm{S} \\
\mathrm{M}\end{array}$ & $\begin{array}{c}\mathrm{T} \\
\mathrm{M}\end{array}$ \\
\hline $\begin{array}{l}\mathrm{Alz} \\
\text { ikri } \\
\mathrm{Re} \\
\text { cha } \\
\mathrm{n}\end{array}$ & 77 & 83 & 80 & $\begin{array}{l}8 \\
0\end{array}$ & $\begin{array}{l}7 \\
8\end{array}$ & $\begin{array}{c}\mathrm{S} \\
\mathrm{M}\end{array}$ & $\begin{array}{c}\mathrm{T} \\
\mathrm{M}\end{array}$ & $\begin{array}{c}\mathrm{S} \\
\mathrm{M}\end{array}$ & $\begin{array}{l}\mathrm{K} \\
\mathrm{M}\end{array}$ \\
\hline An & 77 & 82 & 73 & 8 & 7 & $\mathrm{M}$ & $\mathrm{C}$ & $\mathrm{S}$ & $\mathrm{K}$ \\
\hline
\end{tabular}

\begin{tabular}{|c|c|c|c|c|c|c|c|c|c|}
\hline $\begin{array}{l}\text { gga } \\
\text { Put } \\
\text { ra }\end{array}$ & & & & 0 & 7 & & & $\mathrm{M}$ & $\mathrm{M}$ \\
\hline $\begin{array}{l}\text { An } \\
\text { ggi } \\
\text { ni } \\
\text { Sar } \\
\text { ah }\end{array}$ & 84 & 86 & 82 & $\begin{array}{l}8 \\
4\end{array}$ & $\begin{array}{l}8 \\
5\end{array}$ & $\begin{array}{c}\mathrm{S} \\
\mathrm{M}\end{array}$ & $\begin{array}{l}\mathrm{K} \\
\mathrm{M}\end{array}$ & $\mathrm{M}$ & $\begin{array}{l}\mathrm{K} \\
\mathrm{M}\end{array}$ \\
\hline $\begin{array}{l}\text { An } \\
\text { jan } \\
\text { iva } \\
\text { Em } \\
\text { ilia }\end{array}$ & 88 & 84 & 83 & $\begin{array}{l}8 \\
6\end{array}$ & 0 & $\begin{array}{l}\mathrm{K} \\
\mathrm{M}\end{array}$ & $\begin{array}{c}\mathrm{S} \\
\mathrm{M}\end{array}$ & $\begin{array}{c}\mathrm{T} \\
\mathrm{M}\end{array}$ & $\begin{array}{c}\mathrm{S} \\
\mathrm{M}\end{array}$ \\
\hline $\begin{array}{l}\text { An } \\
\text { nis } \\
\text { a } \\
\text { Ali } \\
\text { via }\end{array}$ & 89 & 87 & 89 & $\begin{array}{l}8 \\
4\end{array}$ & $\begin{array}{l}8 \\
9\end{array}$ & $\begin{array}{l}\mathrm{K} \\
\mathrm{M}\end{array}$ & $\mathrm{M}$ & $\begin{array}{c}\mathrm{C} \\
\mathrm{M}\end{array}$ & $\mathrm{M}$ \\
\hline $\begin{array}{l}\text { An } \\
\text { nis } \\
\text { a } \\
\text { Sa } \\
\text { hab } \\
\text { ira } \\
\text { h }\end{array}$ & 82 & 80 & 80 & $\begin{array}{l}8 \\
5\end{array}$ & $\begin{array}{l}8 \\
4\end{array}$ & $\mathrm{C}$ & $\begin{array}{c}\mathrm{S} \\
\mathrm{M}\end{array}$ & $\begin{array}{c}\mathrm{C} \\
\mathrm{M}\end{array}$ & $\mathrm{M}$ \\
\hline
\end{tabular}

Sumber: Olah Data (2020)

Dari data awal diatas, akan diolah menggunakan metode MOORA. Tahapan-tahapan dalam metode MOORA adalah sebagai berikut:

1. Menentukan kriteria kriteria dan pembobotan

Bobot kriteria telah didapat dari penjelasan sebelumnya, yaitu pada sub bab perhitungan metode SAW, nilai bobot kriteria tertera pada tabel IV.2

2. Pembobotan Tiap Kriteria

Dari masing-masing kriteria yang telah ditentukan, maka akan ditentukan pembobotan. Berikut bobot dari masing masing kriteria. Tabel.16 Bobot Kriteria Penilaian

\begin{tabular}{|c|c|c|c|}
\hline Kode & Kriteria & Type & Bobot \\
\hline C1 & $\begin{array}{c}\text { Nilai Rata-rata } \\
\text { Matematika }\end{array}$ & Benefit & 5 \\
\hline C2 & $\begin{array}{c}\text { Nilai Rata-rata Bahasa } \\
\text { Indonesia }\end{array}$ & Benefit & 4,5 \\
\hline C3 & $\begin{array}{c}\text { Nilai Rata-rata Bahasa } \\
\text { Inggris }\end{array}$ & Benefit & 4 \\
\hline C4 & Nilai Rata-rata IPA & Benefit & 3,5 \\
\hline C5 & Nilai Rata-rata IPS & Benefit & 3 \\
\hline C6 & Minat Siswa IPA & Benefit & 2,5 \\
\hline C7 & Minat Siswa IPS & Benefit & 2 \\
\hline C8 & Saran Orang Tua IPA & Benefit & 1,5 \\
\hline
\end{tabular}


\begin{tabular}{|l|l|l|l|} 
C9 & Saran Orang Tua IPS & Benefit & 1 \\
\hline
\end{tabular} Sumber: Olah Data (2020)

3. Input Nilai Fuzzy Pada Setiap Alternatif

Tabel IV.17 Nilai Fuzzy Setiap Kriteria Untuk Setiap Alternatif

\begin{tabular}{|c|c|c|c|c|c|c|c|c|c|c|c|}
\hline \multirow{3}{*}{$\begin{array}{l}N \\
\mathrm{O}\end{array}$} & \multirow{3}{*}{$\begin{array}{c}\mathrm{K} \\
\mathrm{od} \\
\mathrm{e}\end{array}$} & \multirow{3}{*}{$\begin{array}{l}\text { Alte } \\
\text { rnati } \\
\text { f }\end{array}$} & \multicolumn{9}{|c|}{ Nilai } \\
\hline & & & $\mathrm{C}$ & $\mathrm{C}$ & $\mathrm{C}$ & $\mathrm{C}$ & $\mathrm{C}$ & $\mathrm{C}$ & $\mathrm{C}$ & $\mathrm{C}$ & $\mathrm{C}$ \\
\hline & & & 1 & 2 & 3 & 4 & 5 & 6 & 7 & 8 & 9 \\
\hline 1 & S1 & $\begin{array}{l}\text { Ah } \\
\text { mad } \\
\text { Pray } \\
\text { udha }\end{array}$ & 4 & 4 & 4 & 3 & 4 & 5 & 2 & 5 & 1 \\
\hline 2 & S2 & $\begin{array}{l}\text { Alzi } \\
\text { kri } \\
\text { Rec } \\
\text { han }\end{array}$ & 3 & 4 & 3 & 3 & 3 & 5 & 1 & 5 & 2 \\
\hline 3 & S3 & $\begin{array}{l}\text { Ang } \\
\text { ga } \\
\text { Putr } \\
\text { a }\end{array}$ & 3 & 4 & 3 & 3 & 3 & 4 & 3 & 5 & 2 \\
\hline 4 & S4 & $\begin{array}{l}\text { Ang } \\
\text { gini } \\
\text { Sara } \\
\text { h }\end{array}$ & 4 & 4 & 4 & 4 & 4 & 5 & 2 & 3 & 2 \\
\hline 5 & S5 & $\begin{array}{l}\text { Anja } \\
\text { niya } \\
\text { Emil } \\
\text { ia }\end{array}$ & 4 & 4 & 4 & 4 & 4 & 2 & 5 & 1 & 5 \\
\hline 6 & S6 & $\begin{array}{l}\text { Ann } \\
\text { isa } \\
\text { Aliv } \\
\text { ia }\end{array}$ & 4 & 4 & 4 & 4 & 4 & 2 & 4 & 3 & 4 \\
\hline 7 & S7 & $\begin{array}{l}\text { Ann } \\
\text { isa } \\
\text { Saha } \\
\text { bira } \\
\mathrm{h}\end{array}$ & 4 & 3 & 3 & 4 & 4 & 3 & 5 & 3 & 4 \\
\hline
\end{tabular}

Sumber: Olah Data (2020)

4. Merubah nilai matriks keputusan

Dari nilai fuzzy setiap kriteria untuk setiap alternatif, maka akan diubah menjadi matriks keputusan. Adapun matriks keputusan pada penelitian ini adalah sebagai berikut:

$$
\mathrm{x}=\left(\begin{array}{lllllllll}
4 & 4 & 4 & 3 & 4 & 5 & 2 & 5 & 1 \\
3 & 4 & 3 & 3 & 3 & 5 & 1 & 5 & 2 \\
3 & 4 & 3 & 3 & 3 & 4 & 3 & 5 & 2 \\
4 & 4 & 4 & 4 & 4 & 5 & 2 & 3 & 2 \\
4 & 4 & 4 & 4 & 4 & 2 & 5 & 1 & 5 \\
4 & 4 & 4 & 4 & 4 & 2 & 4 & 3 & 4 \\
4 & 3 & 3 & 4 & 4 & 3 & 5 & 3 & 4
\end{array}\right)
$$

5. Matriks Kinerja Ternormalisasi

Perhitungan detail dari untuk tiap kriteria dan alternatif adalah sebagai berikut:

$$
\begin{gathered}
\text { Kriteria } 1(\mathrm{C} 1)=\sqrt{4^{2}+3^{2}+3^{2}+4^{2}+4^{2}}+4^{2}+4^{2}=9,899 \\
\mathrm{~S} 11=4 / 9,899=0,404 \\
\mathrm{~S} 21=3 / 9,899=0,303 \\
\mathrm{~S} 31=3 / 9,899=0,303 \\
\mathrm{~S} 41=4 / 9,899=0,404 \\
\mathrm{~S} 51=4 / 9,899=0,404 \\
\mathrm{~S} 61=4 / 9,899=0,404 \\
\mathrm{~S} 71=4 / 9,899=0,404
\end{gathered}
$$

Kriteria $2(C 2)=\sqrt{4^{2}+4^{2}+4^{2}+4^{2}+4^{2}}+4^{2}+3^{2}=10,246$

$$
\begin{array}{ll}
\text { S12 }=4 / 10,246 & =0,390 \\
\text { S22 }=4 / 10,246 & =0,390 \\
\text { S32 }=4 / 10,246 & =0,390 \\
\text { S42 }=4 / 10,246 & =0,390 \\
\text { S52 }=4 / 10,246 & =0,390 \\
\text { S62 }=4 / 10,246 & =0,390 \\
\text { S72 }=3 / 10,246 & =0,293
\end{array}
$$

Kriteria $3(C 3)=\sqrt{4^{2}+3^{2}+3^{2}+4^{2}+4^{2}}+4^{2}+3^{2}=9,539$ $\mathrm{S} 13=4 / 9,539=0,419$

$\mathrm{S} 23=3 / 9,539=0,314$

$\mathrm{S} 33=3 / 9,539=0,314$

$\mathrm{S} 43=4 / 9,539=0,419$

$\mathrm{S} 53=4 / 9,539=0,419$

$\mathrm{S} 63=4 / 9,539=0,419$

$\mathrm{S} 73=3 / 9,539=0,314$

Kriteria $4(C 4)=\sqrt{3^{2}+3^{2}+3^{2}+4^{2}+4^{2}}+4^{2}+4^{2}=9,539$

$\mathrm{S} 14=3 / 9,539=0,314$

$\mathrm{S} 24=3 / 9,539=0,314$

$\mathrm{S} 34=3 / 9,539=0,314$

$\mathrm{S} 44=4 / 9,539=0,419$

$\mathrm{S} 54=4 / 9,539=0,419$

$\mathrm{S} 64=4 / 9,539=0,419$

$\mathrm{S} 74=4 / 9,539=0,419$

Kriteria $5(C 5)=\sqrt{4^{2}+3^{2}+3^{2}+4^{2}+} 4^{2}+4^{2}+4^{2}=9,899$

$\mathrm{S} 15=4 / 9,899=0,404$

$\mathrm{S} 25=3 / 9,899=0,303$

$\mathrm{S} 35=3 / 9,899=0,303$

$\mathrm{S} 45=4 / 9,899=0,404$

$\mathrm{S} 55=4 / 9,899=0,404$

$\mathrm{S} 65=4 / 9,899=0,404$

$\mathrm{S} 75=4 / 9,899=0,404$

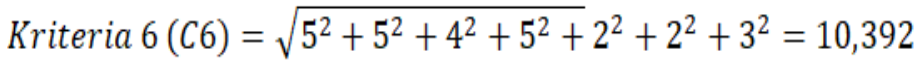

$\mathrm{S} 16=5 / 10,392=0,481$

$\mathrm{S} 26=5 / 10,392=0,481$

$\mathrm{S} 36=4 / 10,392=0,385$

$\mathrm{S} 46=5 / 10,392=0,481$

JISICOM (Journal of Information System, Informatics and Computing)

http://journal.stmikjayakarta.ac.id/index.php/jisicom Telp.+62-21-3905050, e-mail:jisicom@stmikjayakarta.ac.id, jisicom2017@gmail.com 
$\mathrm{S} 56=2 / 10,392=0,192$

$\mathrm{S} 66=2 / 10,392=0,192$

$\mathrm{S} 76=3 / 10,392=0,289$
8. Nilai Yi pada Metode MOORA

Kemudian setelah melakukan perkalian anatara $\mathrm{Xij}$ dan $\mathrm{Wj}$ maka berikutnya adalah

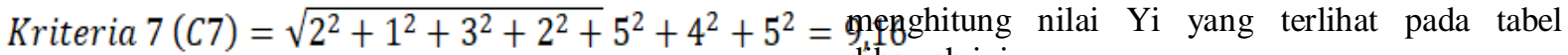
dibawah ini:

$\mathrm{S} 17=2 / 9,165=0,218$

$\mathrm{S} 27=1 / 9,165=0,109$

$\mathrm{S} 37=3 / 9,165=0,327$

$\mathrm{S} 47=2 / 9,165=0,218$

$\mathrm{S} 57=5 / 9,165=0,546$

$\mathrm{S} 67=4 / 9,165=0,436$

$\mathrm{S} 77=5 / 9,165=0,546$

Kriteria $8(C 8)=\sqrt{5^{2}+5^{2}+5^{2}+3^{2}+1^{2}}+3^{2}+3^{2}=10,148$

$\mathrm{S} 18=5 / 10,148=0,493$

$\mathrm{S} 28=5 / 10,148=0,493$

$\mathrm{S} 38=5 / 10,148=0,493$

$\mathrm{S} 48=3 / 10,148=0,296$

$\mathrm{S} 58=1 / 10,148=0,099$

$\mathrm{S} 68=3 / 10,148=0,296$

$\mathrm{S} 78=3 / 10,148=0,296$

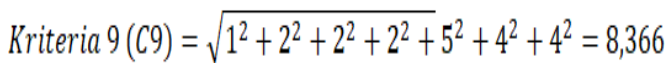

$$
\begin{aligned}
& \mathrm{S} 19=1 / 8,366=0,120 \\
& \mathrm{~S} 29=2 / 8,366=0,239 \\
& \mathrm{~S} 39=2 / 8,366=0,239 \\
& \mathrm{~S} 49=2 / 8,366=0,239 \\
& \mathrm{~S} 59=5 / 8,366=0,598 \\
& \mathrm{~S} 69=4 / 8,366=0,478 \\
& \text { S79 }=4 / 8,366=0,478
\end{aligned}
$$

6. Perhitungan nilai ternormalisasi maka diperoleh matriks nilai normalisasi sebagai berikut:

$\left(\begin{array}{lllllllll}0,404 & 0,390 & 0,419 & 0,314 & 0,404 & 0,481 & 0,218 & 0,493 & 0,120\end{array}\right.$

$\begin{array}{lllllllll}0,303 & 0,390 & 0,314 & 0,314 & 0,303 & 0,481 & 0,109 & 0,493 & 0,239\end{array}$

$\begin{array}{lllllllll}0,303 & 0,390 & 0,314 & 0,314 & 0,303 & 0,384 & 0,327 & 0,493 & 0,239\end{array}$

$x_{i j}=\begin{array}{lllllllll}0,404 & 0,390 & 0,419 & 0,419 & 0,404 & 0,481 & 0,218 & 0,296 & 0,239\end{array}$

$\begin{array}{lllllllll}0,404 & 0,390 & 0,419 & 0,419 & 0,404 & 0,192 & 0,546 & 0,099 & 0,598\end{array}$

$\begin{array}{lllllllll}0,404 & 0,390 & 0,419 & 0,419 & 0,404 & 0,192 & 0,436 & 0,296 & 0,478\end{array}$

$\begin{array}{lllllllll}0,404 & 0,293 & 0,314 & 0,419 & 0,404 & 0,288 & 0,546 & 0,296 & 0,478\end{array}$

7. Hasil perkalian bobot disertakan pencarian y ternormalisasi maka nilai Xij*Wj yaitu sebagai berikut:

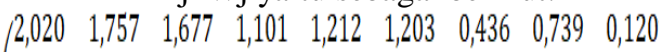
$\begin{array}{lllllllll}1,515 & 1,757 & 1,258 & 1,101 & 0,909 & 1,203 & 0,218 & 0,739 & 0,239\end{array}$ $\begin{array}{lllllllll}1,515 & 1,757 & 1,258 & 1,101 & 0,909 & 0,962 & 0,655 & 0,739 & 0,239\end{array}$

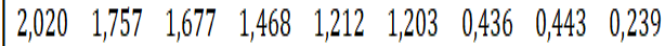
$\begin{array}{lllllllll}2,020 & 1,757 & 1,677 & 1,468 & 1,212 & 0,481 & 1,091 & 0,148 & 0,598\end{array}$ $\begin{array}{lllllllll}2,020 & 1,757 & 1,677 & 1,468 & 1,212 & 0,481 & 0,873 & 0,443 & 0,478\end{array}$ $\left(\begin{array}{lllllllll}2,020 & 1,318 & 1,258 & 1,468 & 1,212 & 0,722 & 1,091 & 0,443 & 0,478\end{array}\right)$
Tabel.18 Nilai Yi Pada Metode MOORA

\begin{tabular}{|c|c|c|c|}
\hline $\begin{array}{c}\text { Alter } \\
\text { natif }\end{array}$ & $\begin{array}{c}\text { Maximum } \\
(\mathrm{C} 1+\mathrm{C} 2+\mathrm{C} 3+\mathrm{C} 4+\mathrm{C} 5+\mathrm{C} 6 \\
+\mathrm{C} 7+\mathrm{C} 8+\mathrm{C} 9)\end{array}$ & $\begin{array}{c}\text { Minim } \\
\mathrm{um}()\end{array}$ & $\mathrm{Yi}$ \\
\hline S1 & 10,260 & 0 & $\begin{array}{c}10,2 \\
60\end{array}$ \\
\hline S2 & 8,933 & 0 & $\begin{array}{c}8,93 \\
3\end{array}$ \\
\hline S3 & 9,127 & 0 & $\begin{array}{c}9,12 \\
7\end{array}$ \\
\hline S4 & 10,451 & 0 & $\begin{array}{c}10,4 \\
51\end{array}$ \\
\hline S5 & 10,446 & 0 & $\begin{array}{c}10,4 \\
46\end{array}$ \\
\hline S6 & 10,404 & 0 & 0,4 \\
\hline & 9,986 & 0 & 6,98 \\
\hline S7 & & & \\
\hline
\end{tabular}

Sumber: Olah Data (2020)

9.Hasil Perangkingan Alternatif

Langkah terakhir setelah melakukan proses perhitungan Nilai Optimasi adalah melakukan perangkingan untuk mengetahui nilai terbesar sampai dengan nilai terkecil.

Tabel.19 Perangkingan Alternatif

\begin{tabular}{|c|l|c|c|}
\hline Alternatif & Keterangan & Skor & Peringkat \\
\hline S1 & $\begin{array}{l}\text { Ahmad } \\
\text { Prayudha }\end{array}$ & 10,260 & 4 \\
\hline S2 & $\begin{array}{l}\text { Alzikri } \\
\text { Rechan }\end{array}$ & 8,933 & 7 \\
\hline S3 & Angga Putra & 9,127 & 6 \\
\hline S4 & $\begin{array}{l}\text { Anggini } \\
\text { Sarah }\end{array}$ & 10,451 & 1 \\
\hline S5 & $\begin{array}{l}\text { Anjaniva } \\
\text { Emilia }\end{array}$ & 10,446 & 2 \\
\hline S6 & Annisa Alivia & 10,404 & 3 \\
\hline S7 & $\begin{array}{l}\text { Annisa } \\
\text { Sahabirah }\end{array}$ & 9,986 & 5 \\
\hline
\end{tabular}

C. Hasil Pembahasan

Dari proses perhitungan yang dilakukan dengan menerapkan metode SAW dan MOORA dalam penerapan pemilihan jurusan, dapat diambil kesimpulan bahwa dengan menerapkan kedua metode tersebut di dapat hasil perangkingan yang
Sumber: Olah Data (2020)

JISICOM (Journal of Information System, Informatics and Computing)

http://journal.stmikjayakarta.ac.id/index.php/jisicom Telp.+62-21-3905050, e-mail:jisicom@stmikjayakarta.ac.id, jisicom2017@gmail.com 


\section{Journal of Information System, Informatics and Computing}

sama. Dimana alternatif yang bernama Anggini Sarah dengan nilai optimasi dengan metode SAW sebesar 24,600 dan metode MOORA sebesar 10,451 merupakan nilai optimasi terbesar, sedangkan nilai optimasi terendah adalah alternatif yang bernama Alzikri Rechan dengan optimasi menggunakan metode SAW sebesar 20,925 dan metode MOORA sebesar 8,933. Hasil perhitungan diatas dengan menggunakan metode SAW dan MOORA, peringkat 1 sampai peringkat 4 masuk ke dalam jurusan IPA dan sisanya peringkat 5 sampai 7 masuk ke dalam jurusan IPS. Maka siswa yang masuk jurusan IPA adalah Anggini Sarah, Anjaniva Emilia, Annisa Alivia, Ahmad Prayudha dan yang masuk IPS adalah Annisa Sahabirah, Angga Putra, Alzikri

\section{KESIMPULAN}

Dari hasil yang didapat, maka dapat diambil kesimpulan bahwa metode SAW dan MOORA

\section{REFERENSI}

[1] R. Taufiq and T. Akademik, "KEPUTUSAN KEJURUSAN MENGGUNAKAN METODE SIMPLE ADDITIVE WEIGHTING ( SAW ) DI SMA NEGRI 15 TANGERANG DESIGNING MAJORS DECISION SUPPORT SYSTEM USING SIMPLE ADDITIVE,' J. TI Atma Luhur, vol. 4, no. 1, p. 104, 2017.

[2] C. Journal and U. Janabadra, "Sistem Pendukung Keputusan Konsentrasi dan Peminatan Prodi Teknik Informatika Universitas Janabadra Yogyakarta," Citec J., vol. 3, no. 4, p. 308, 2016.

[3] S. Pendukung, K. Pemilihan, J. Pada, Y. Muhammad, N. By, and U. The, "Decision Support System for Selection of Majors at The," (Journal Informatics Telecommun. Eng., vol. 2, no. 2 , p. $128,2019$.

[4] A. M. Ismaulina, KEPUTUSAN MAHASISWA DAN FAKTOR-FAKTOR YANG MMPENGARUHI PEMILIHAN JURUSAN $B A R U$. CV. AA. RIZKY.
Rechan, hasil perangkingan ditampilkan dalam bentuk grafik dibawah ini.

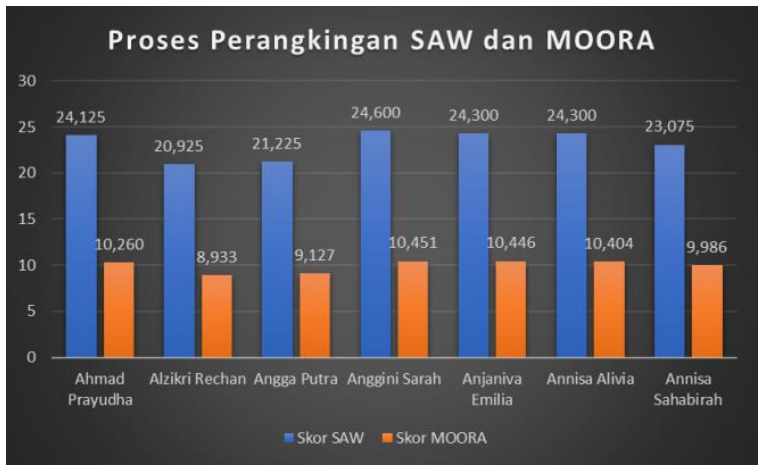

Sumber: Olah Data (2020)

Gambar IV.1 Grafik Perangkingan

dapat digunakan dalam pengambilan keputusan pemilihan jurusan pada SMA N 108 Jakarta yang berarti $\mathrm{H} 1$ diterima dan $\mathrm{H} 0$ ditolak.

[5] P. HENI, BUKU AJAR SISTEM KEPUTUSAN. YOGYAKARTA: DEEPUBLISH, 2016.

[6] D. Nofriansyah, MULTI CRITERIA DECISION MAKING (MDCM) PADA SISTEM PENDUKUNG KEPUTUSAN. YOGYAKARTA: DEEPUBLISH, 2017.

[7] D. Nofriansyah, KONSEP DATA MINING VS SISTEM PENDUKUNG KEPUTUSAN. YOGYAKARTA: DEEPUBLISH, 2014.

[8] M. ANDI, MICROSOFT EXCEL 2016 UNTUK PEMULA. YOGYAKARTA: MADCOMS, 2016.

JISICOM (Journal of Information System, Informatics and Computing)

http://journal.stmikjayakarta.ac.id/index.php/jisicom Telp.+62-21-3905050, e-mail:jisicom@stmikjayakarta.ac.id,jisicom2017@gmail.com 